
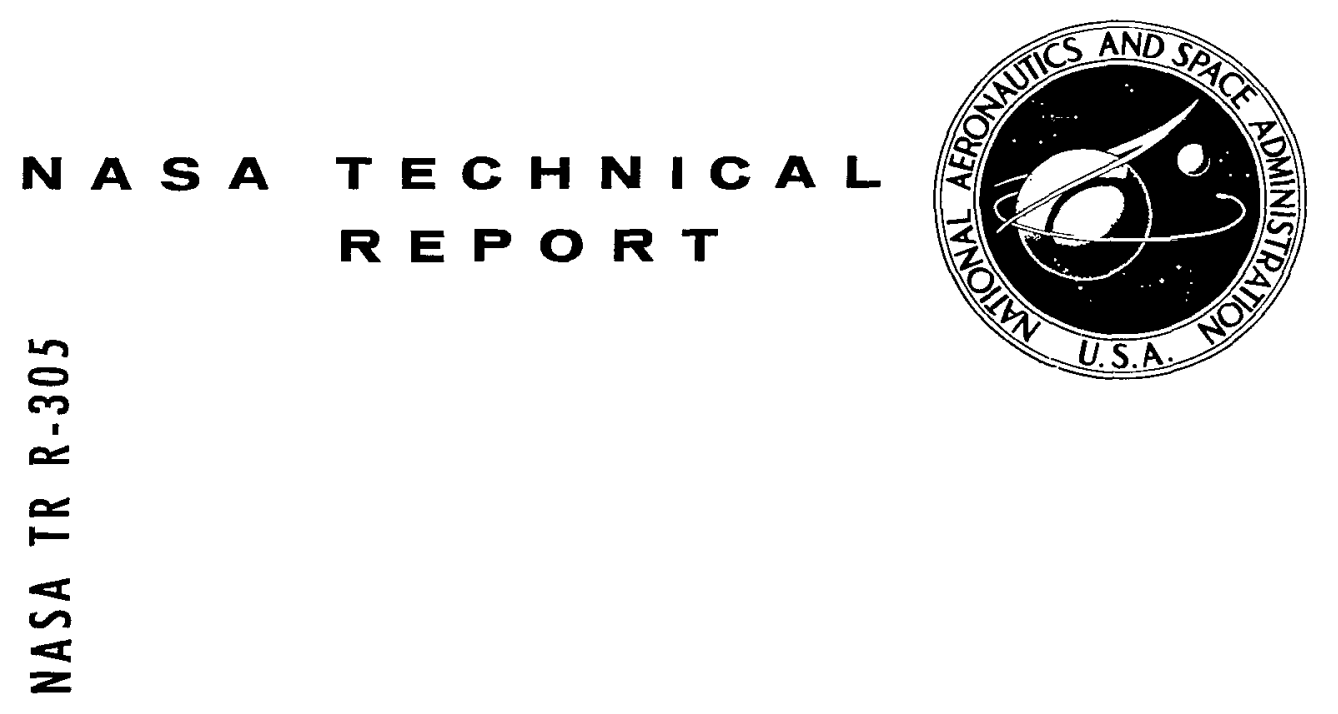

NASA IR R-305 C. 1

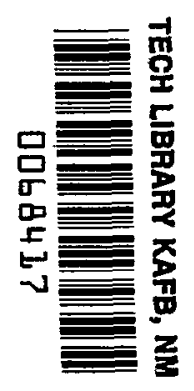

LOAN COPY: RETURN TO

AFWL (WLIL-2)

KIRTLAND AFB, N MEX

\title{
EFFECTS OF LITHIUM AND OXYGEN LOSSES \\ ON THE MAGNETIC AND CRYSTALLOGRAPHIC PROPERTIES OF SPINEL LITHIUM FERRITE
}

by D. H. Ridgley, H. Lessoff, and J. D. Childress

Electronics Research Center

Cambridge, Mass.

NATIONAL AERONAUTICS AND SPACE ADMINISTRATION - WASHINGTON, D. C. - MARCH 1969 
EFFECTS OF LITHIUM AND OXYGEN LOSSES ON THE MAGNETIC AND CRYSTALLOGRAPHIC PROPERTIES OF SPINEL LITHIUM FERRITE

By D. H. Ridgley, H. Lessoff, and J. D. Childress

Electronics Research Center

Cambridge, Mass.

\section{NATIONAL AERONAUTICS AND SPACE ADMINISTRATION}

For sale by the Clearinghouse for Federal Scientific and Technical Information Springfield, Virginia 22151 - CFSTI price $\$ 3.00$ 


\section{EFFECTS OF IITHIUM AND OXYGEN LOSSES \\ ON THE MAGNETIC AND CRYSTALLOGRAPHIC PROPERTIES \\ OF SPINEL LITHIUM FERRITE*}

By D. H. Ridgley, H. Lessoff, and J. D. Childress

Electronics Research Center

\section{SUMMARY}

The magnetic moment and lattice parameter of stoichiometric spinel lithium ferrite $\left(\mathrm{Ii}_{0.5} \mathrm{Fe}_{2.5} \mathrm{O}_{11}\right.$ ) has been reliably established, respectively, as $3736 \pm 20 \mathrm{G}$ at $25^{\circ} \mathrm{C}$ and $8.3293 \pm 0.0005 \AA$ at $28^{\circ} \mathrm{C}$. Under 1 atmosphere of oxygen, lithium ferrite loses both oxygen and lithium oxide in increasing amounts with increasing temperature above about 950 to $1000^{\circ} \mathrm{C}$. Slow cooling and annealing at a lower temperature bring about reoxidation and precipitation of $\alpha-\mathrm{Fe}_{2} \mathrm{O}_{3}$. Rapid cooling from the sintering temperature leads to anomalously high magnetic moments and lattice parameters; lower temperature anneals and very slow cooling rates produce anomalously low moment values. Intermediate cooling procedures lead to properties intermediate between these properties.

The properties of the resultant product can be explained very satisfactorily on the basis of solid solutions between lithium ferrite and $\mathrm{Fe}_{3} \mathrm{O}_{4}$ with rapid cooling and on the basis of solid solution between lithium ferrite and $\gamma-\mathrm{Fe}_{2} \mathrm{O}_{3}$ with a second phase of $\alpha-\mathrm{Fe}_{2} \mathrm{O}_{3}$ on lower temperature annealing and slow-cooling.

It is doubtful whether the second limiting case described above can occur to any appreciable extent because of the tendency of the products to precipitate the excess $\mathrm{Fe}_{2} \mathrm{O}_{3}$ as $\alpha-\mathrm{Fe}_{2} \mathrm{O}_{3}$.

Finally one is led to the following conclusion: The lithium oxide volatilization is associated with oxygen loss under moderate oxygen pressure ( $\sim$ atmosphere), but the oxygen loss can be shown to be the primary cause of the lithium loss under normal sintering conditions.

\section{INTRODUCTION}

Although spinel lithium ferrite has been studied by a number of workers (refs. 1-14), the properties of the stoichiometric material remain very much in doubt. Reported magnetic moments

\footnotetext{
*Presented in part at the Seventieth Annual Meeting, The American Ceramic Society, Chicago, Ill., April 24, 1968 (Electronics Division, No. 34-E-68).
} 
$\left(4 \pi M_{S}\right.$ ) vary from 2400 (ref. 12b to 3900 gauss (ref. 15), lattice parameters from 8.314 to $8.37 \AA$ (ref. 15), Curie temperatures from 590 to $680^{\circ} \mathrm{C}$, and resistivities are reported from a few ohmcentimeters to values many orders of magnitude higher. Prior work on lithium ferrite has been reviewed and summarized by von Alouck (ref. 15). Much consideration has been given to the order-disorder transition occurring near $750^{\circ} \mathrm{C}$, but little concern has been shown for the effects of ferrous ion or lack of stoichiometry. Much of the variation in properties can probably be traced to these last factors and, thus, to the preparation techniques. Only occasionally are the materials characterized by x-ray diffraction and rarely are such characterizations reported in detail.

It is generally accepted that lithium volatilizes rapidly from lithium ferrite and similar materials, but the quantitative evidence presented has been limited. This results from the absence of a good analytical method for lithium, the errors of analysis being comparable in many cases to the expected lithium deficiencies.

Strickler and Roy (ref. 10) studied the $\mathrm{Li}_{2} \mathrm{O}-\mathrm{Fe}_{2} \mathrm{O}_{3}$ system and found that the solubility of $\mathrm{LiFeO}_{2}$ in $\mathrm{Li}_{0.5} \mathrm{Fe}_{2.5} \mathrm{O}_{4}$ to be less than 5 percent and probably less than 1 percent. Others (refs. $7,8)$ have reported studies of materials analyzed and found to have compositions containing large excesses of $\mathrm{Li}_{2} \mathrm{O}$. This discrepancy is not insignificant.

A study of the effects of sintering conditions on the magnetic and crystallographic properties of lithium ferrite was made and are reported in this document. The experimental details are given in section II, the observed results in section III, and the authors' interpretations in section IV.

\section{EXPERIMENTAL METHODS}

\section{Materials Preparation}

All samples were prepared from reagent grade $\mathrm{Li}_{2} \mathrm{CO}_{3}$ and $\gamma-\mathrm{Fe}_{2} \mathrm{O}_{3}$. The $\gamma-\mathrm{Fe}_{2} \mathrm{O}_{3}$ was analyzed by standard techniques; the $\mathrm{Li}_{2} \mathrm{CO}_{3}$ was analyzed by acid titration, which requires the assumption of no significant quantity of metal ions other than lithium. The quantities of $\mathrm{Li}_{2} \mathrm{CO}_{3}$ and $\gamma-\mathrm{Fe}_{2} \mathrm{O}_{3}$ were adjusted in accordance with these analyses.

The calculated amounts of $\mathrm{Li}_{2} \mathrm{CO}_{3}$ and $\gamma-\mathrm{Fe}_{2} \mathrm{O}_{3}$ were combined and milled 8 hours under ethanol in an attritor. This product was dried, passed through a 100 mesh screen, and heated in air at $700^{\circ} \mathrm{C}$ for 4 hours. The resulting material was remilled under

ethanol, as previously, dried, and screened. 
This prefired $\mathrm{Li}_{2} \mathrm{CO}_{3}-\mathrm{Fe}_{2} \mathrm{O}_{3}$ material was fired under 1 atmosphere of oxygen at temperatures from 900 to $1400^{\circ} \mathrm{C}$ for times varying from 1 minute to 72 hours after the samples reached temperature. The majority of the samples were fired for either 4 or 24 hours. The heat treatments were concluded by varied cooling schedules, including sharp cooling by rapid removal of the samples from the furnace to room ambient conditions, and by controlled cooling under 1 atmosphere of oxygen at rates varying from 20 to $320^{\circ} \mathrm{C} / \mathrm{hr}$. The sharply cooled and slowly cooled samples for each sintering schedule were heated simultaneously under oxygen, and then one sample container was removed and sharply cooled in air, while the other was cooled slowly at a controlled rate under 1 atmosphere of oxygen. All such samples were characterized by $x$-ray diffraction and magnetic moment measurements. The previously sharply cooled samples were subsequently annealed in oxygen at $900^{\circ} \mathrm{C}$ for 8 hours, and then cooled to room temperature at $10^{\circ} \mathrm{C} / \mathrm{hr}$. The $\mathrm{x}$-ray diffraction and magnetic moment measurements were then repeated.

\section{Magnetic Measurements}

Magnetic moments of the products, after the various heating schedules, were determined at room temperature $\left(25^{\circ} \mathrm{C}\right)$ using a Princeton Applied Research vibrating sample magnetometer (Foner type) at an applied field of $8 \mathrm{kOe}$. To reduce the effects of temperature fluctuations, a selected lithium ferrite sample was compared with nickel (99.999\%) in a series of a large number of measurements. All products were compared with this one product. The probable error of the individual magnetic measurements is estimated to be about $\pm 25 \mathrm{G}$. The value assumed for nickel was $54.39 \mathrm{emu} / \mathrm{g}$.

\section{X-ray Diffraction Measurements}

Lattice parameters of all products were determined using a Norelco diffractometer with $\mathrm{Cu} K \alpha$ radiation $\left(\mathrm{K} \alpha_{1}=1.54051 \AA\right.$, $\left.\mathrm{K} \alpha_{2}=1.54433 \AA\right)$, and an Advanced Metals Research focusing LiF crystal monochromator in the diffracted beam, a scintillation counter detector, and pulse-height discriminator. Scanning speed was $1 / 8 \mathrm{deg} 2 \theta / \mathrm{min}$ with a $1-\sec$ time constant; data was recorded as 1 deg $2 \theta / i n$. of chart length. Other measurement conditions were: standard flat sample without rotation in the plane of the sample surface; 1 deg divergence slit throughout the scan; horizontal divergence of soller slits 4.5 deg. Peak angle positions were taken as the highest point of the peak. All x-ray measurements were made at $28^{\circ} \mathrm{C}$, the ambient temperature of the room which was found to remain constant to within $\pm 1^{\circ} \mathrm{C}$. Lattice parameters calculated from the various peaks with $2 \theta>90$ deg were plotted versus $\cos ^{2} \theta$ and extrapolated to $\cos ^{2} \theta=0$. The lattice parameter of one sample was determined by the extrapolation 
method and also by use of silicon as internal standard; the values found differed by $0.0005 \AA$. The lattice parameter of silicon derived from this same scan using the extrapolation method was $5.4308 \AA$; the I.U.C. value according to Parrish (ref. 16) is 5.43050 at $25^{\circ} \mathrm{C}\left(5.43054 \AA\right.$ at $28^{\circ} \mathrm{C}$ after applying the thermal expansion coefficient) without refraction correction. This latter difference $(-0.003 \AA)$ was applied as a correction to all extrapolated lattice parameters. This difference is thought to arise primarily from a failure of the lattice parameter values calculated from the individual diffraction peaks to be a true linear function of the extrapolation function $\cos ^{2} \theta$. The probable error of the lattice parameter measurements is estimated to be $\pm 0.0005 \AA$.

\section{RESULTS}

The effects of the various heat treatments are shown in Figures 1 and 2. In Figure 1 the moment values plotted are not the true $4 \pi M_{S}$ values since the density increases during the heat treatment, as explained in section IV. The values shown are proportional to the moment per unit weight and are the values which would be obtained if the separate products were prepared under those conditions and were assumed to be stoichiometric lithium ferrite. It can be seen that as the sintering temperature is increased, the moments (Figure l) and the lattice parameters (Figure 2) increase in parallel fashion, both for the sharply cooled and the slowly cooled materials. When the materials originally sharply cooled were annealed at $900^{\circ} \mathrm{C}$ for 8 hours and then cooled very slowly $\left(10^{\circ} \mathrm{C} / \mathrm{hr}\right)$, the moments decreased with increase in the temperature of the initial firing, but the lattice parameters decreased to values differing from each other and from the stoichiometric value, $8.3293 \AA$, only slightly (see section IV).

Each of the x-ray diffraction patterns of the products, after this annealing treatment, showed the presence of $\alpha-\mathrm{Fe}_{2} \mathrm{O}_{3}$, except the sample sintered at $1000^{\circ} \mathrm{C}$ for only 4 hours. All those samples heated at $900^{\circ} \mathrm{C}$ only showed $\alpha-\mathrm{Fe}_{2} \mathrm{O}_{3}$ in the $\mathrm{x}$-ray patterns, regardless of the time at temperature or the rate of cooling; however, this is regarded as the result of incomplete reaction. Because of the relatively low x-ray scattering amplitude of lithium and oxygen, only rather large amounts of $\mathrm{Li}_{2} \mathrm{O}$ (and $\mathrm{Li}_{2} \mathrm{CO}_{3}$ ) could be detected by $x$-ray diffraction methods. No attempt was made to achieve a greater degree of reaction by a series of regrindings and firings.

The relative quantity of $\alpha-\mathrm{Fe}_{2} \mathrm{O}_{3}$ was gauged by the intensity of the 104 peak (the strongest $\alpha-\mathrm{Fe}_{2} \mathrm{O}_{3}$ diffraction) appearing at 


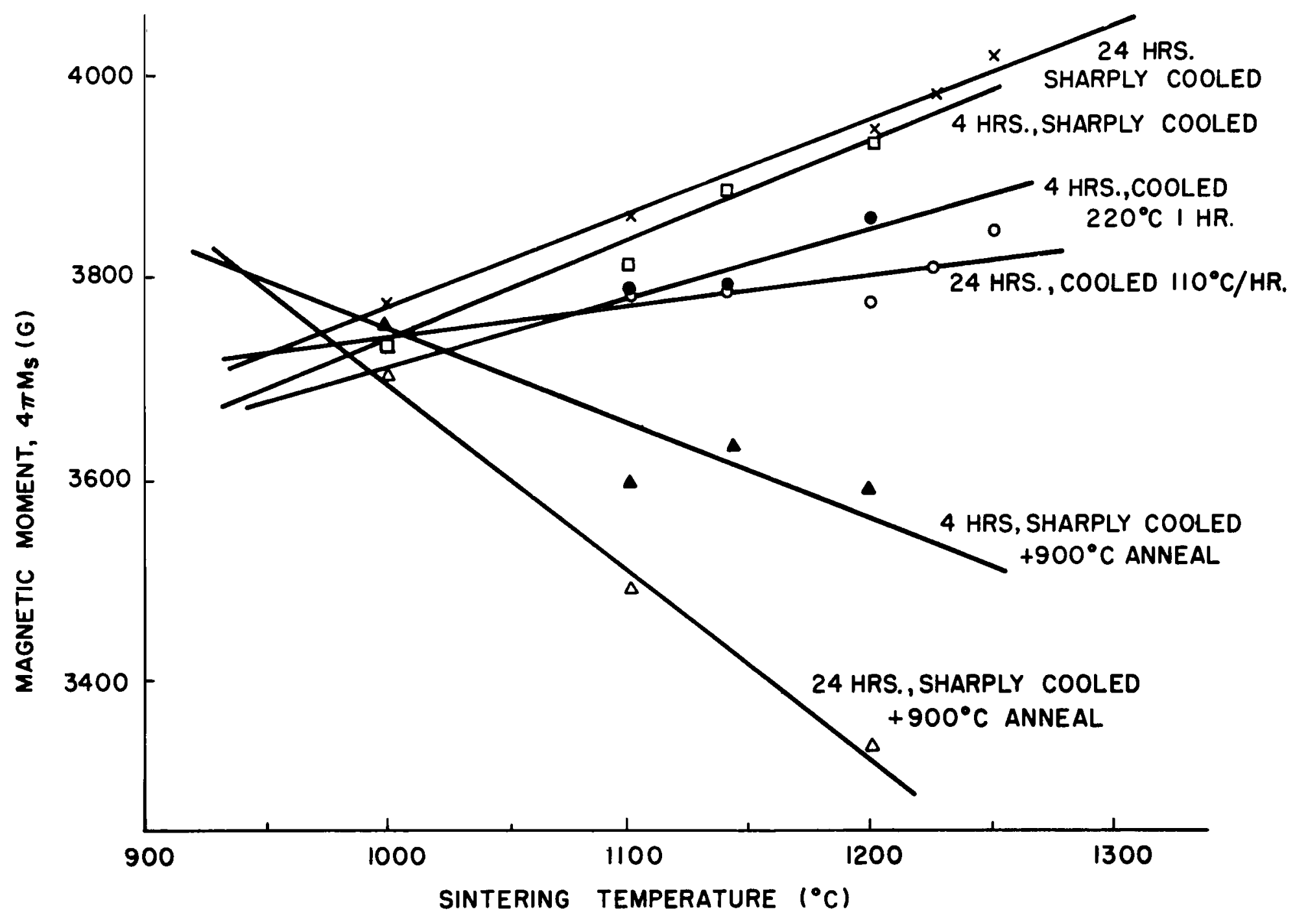

Figure 1.- Effects of sintering temperatures, sintering times, and cooling rate on magnetic moment (density assumed $4.759 \mathrm{~g} / \mathrm{cm}^{3}$.) 


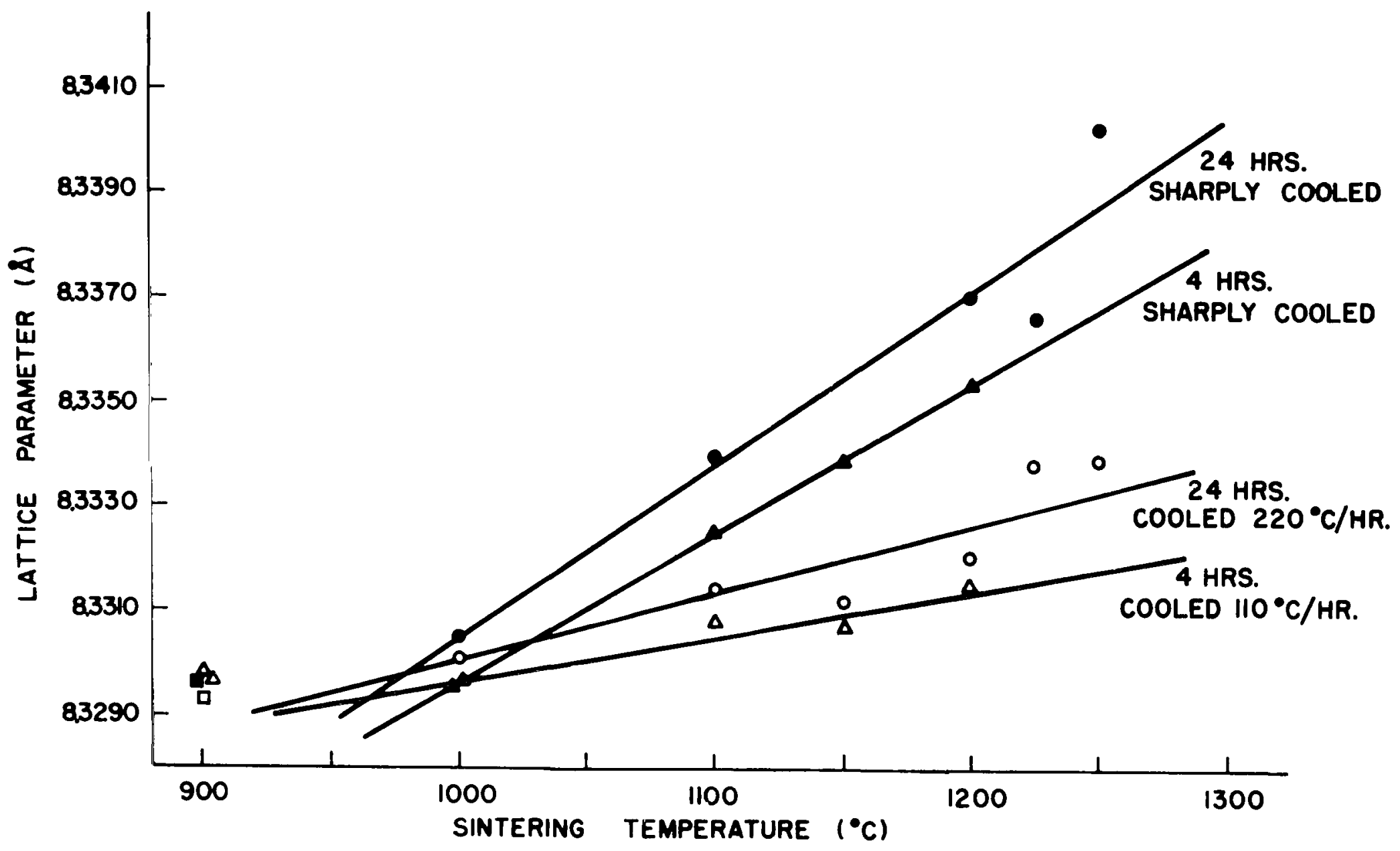

Figure 2.- Effects of sintering temperatures, sintering times, and cooling rates on lattice parameter. 
about $33.30 \mathrm{deg} 2 \theta(\mathrm{d}=2.688 \AA)$. The height of this peak was zero for the sample fired initially 4 hours at $1000^{\circ} \mathrm{C}$, a small bump on the background with 24 hours at $1000^{\circ} \mathrm{C}$; it then increased with increasing temperature and time to become more than one-half the height of the 220 peak of the lithium ferrite phase after 24 hours at $1225^{\circ} \mathrm{C}$. The $\mathrm{x}$-ray diffraction patterns of all samples, except those fired at temperatures of $1300^{\circ} \mathrm{C}$ and higher, showed the superlattice peaks associated with the ordering of the lithium on the octahedral sites. The cooling rate of the sharply cooled samples evidently was not sufficiently rapid to achieve lithium disorder; it has been reported (ref. 6) that the cooling must be accomplished in a matter of.1 to 2 seconds to achieve disorder. Little variation in intensity or width of the x-ray diffraction peaks was noted among the various samples and no clear dependence of the intensity or peak width on the cooling rate was evident.

Attempts were made to obtain a disordered sample by quenching a portion of one of the 4 -hour $-1000^{\circ} \mathrm{C}$ samples into water from $800^{\circ} \mathrm{C}$. The lattice parameter found was $8.331_{4} \AA$ and the moment found was $3758 \mathrm{G}$. Since no large change in moment was observed. on quenching sharply enough to achieve disorder of the lithium, it appears very unlikely that any significant transfer of lithium to tetrahedral sites occurs in the stoichiometric material. The spinel superlattice peaks $(110,210,211,310$, etc.) disappeared from the x-ray diffraction pattern; however, the remaining peaks showed no visible changes in intensity or position. A sensitivity to water and water vapor has been reported* for lithium ferrite; however, no appreciable sensitivity was observed in this experiment. The mechanism of any such action by water in its effect on the properties of lithium ferrite is not known. Kato (ref. 6) reports a lattice parameter of $8.3326 \AA$ for disordered lithium ferrite quenched from $1000^{\circ} \mathrm{C}$ and $8.3296 \AA$ for the ordered material. The chemical analysis reported by kato indicated a lithium deficiency of about 15 percent; however, the analytical procedures for lithium are not the most reliable. The lattice parameter values from NASA-ERC for the stoichiometric material are in good agreement with those of Kato, but an analysis of one of the NASAERC 4-hour-1000 $\mathrm{C}$ samples (presumed stoichiometric) indicated a lithium deficiency of only 0.6 percent (see below). The electrical resistivity reported by Kato for the ordered material is too high to be consistent with large lithium deficiencies, unless the samples had been slowly cooled. It appears that Kato's materials were much more nearly stoichiometric than indicated. Kato reports a slightly lower resistivity for disordered lithium ferrite than for the ordered material.

*B. Frackiewicz, NASA/ERC, private communication 
Efforts were made to achieve disorder in a sample by allowing powder to fall from a furnace $\left(800^{\circ} \mathrm{C}\right.$, I atmosphere oxygen) upon an inclined aluminum plate with one end resting in liquid nitrogen. The superlattice peaks of the x-ray diffraction pattern were considerably reduced in intensity but not completely to zero.

The effects of cooling rate on the magnetic moment and lattice parameter were invéstigated in one series in which all samples were fired at $1100^{\circ} \mathrm{C}$ for 4 hours under 1 atmosphere oxygen, and then subjected to various cooling schedules. The results are tabulated in Table I. The sample designated as $900^{\circ} \mathrm{C}$ anneal was the sample initially sharply cooled, annealed at $900^{\circ} \mathrm{C}$ for 8 hours, and then cooled to room temperature at $10^{\circ} \mathrm{C} / \mathrm{hr}$.

TABLE I

EFFECT OF COOLING RATE ON MAGNETIC MOMENT AND LATTICE PARAMETER*

\begin{tabular}{|c|c|c|}
\hline $\begin{array}{c}\text { Cooling Rate } \\
\left({ }^{\circ} \mathrm{C} / \mathrm{hr}\right)\end{array}$ & $\begin{array}{l}\text { Measured Moment } \\
\qquad\left[4 \pi M_{S} \text { (G) }\right]\end{array}$ & $\begin{array}{c}\text { Lattice Parameter } \\
(\AA)\end{array}$ \\
\hline Sharp & 3808 & $8.332_{8}$ \\
\hline 320 & 3767 & $8.332_{5}$ \\
\hline 220 & 3765 & $8.33 I_{I}$ \\
\hline 110 & 3776 & $8.330_{4}$ \\
\hline 100 & - & $8.330_{5}$ \\
\hline 20 & 3748 & $8.330_{2}$ \\
\hline $\begin{array}{c}900^{\circ} \mathrm{C} \text { Anneal } \\
+10^{\circ} \mathrm{C} / \mathrm{hr}\end{array}$ & $\begin{array}{c}3620 \\
\text { (two phase) }\end{array}$ & - \\
\hline
\end{tabular}

*All samples fired 4 hours at $1100^{\circ} \mathrm{C}$.

A series of heat treatments was carried out at $1200^{\circ} \mathrm{C}$ to investigate, to a limited degree, the rate of attainment of the final properties. In this series, samples were heated at times varying from 1 minute to 24 hours, then rapidly cooled by removing the samples from the furnace and allowing them to cool under ambient room conditions. These results are shown in Figure 3 . From these data, it appears that the rates of increase of the 

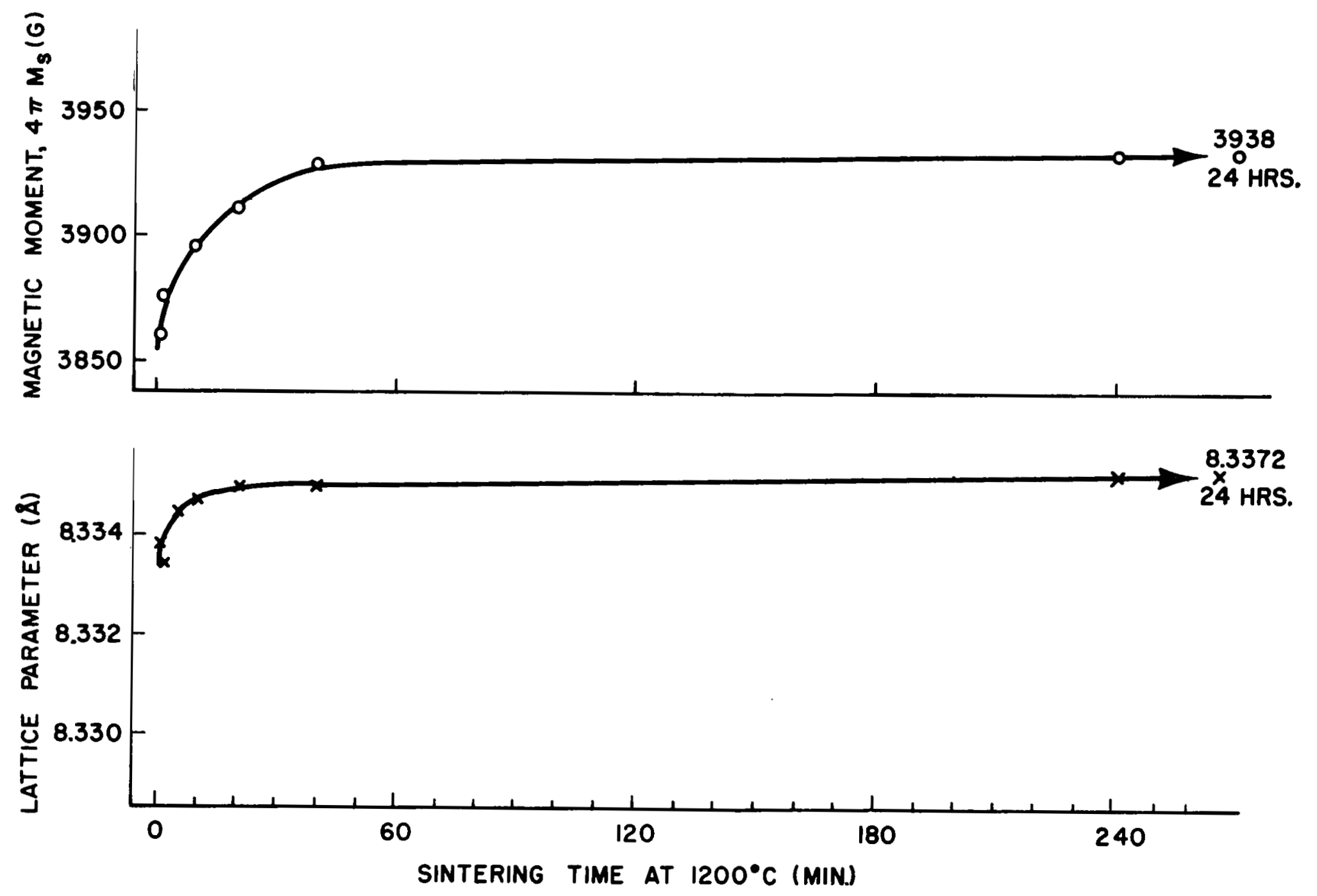

Figure 3.- Effect of time on magnetic moment and lattice parameter at $1200^{\circ} \mathrm{C}$, all samples sharply cooled; the 24 hour values are designated at the right for each property. 
magnetic moment and the lattice parameter at $1200^{\circ} \mathrm{C}$ are very large at first, but rapidly decrease with time, becoming nearly stable after about 40 minutes.

The magnetic moments versus lattice parameters for all single-phase materials have been plotted in Figure 4, regardless of the heat treatment. The degree of departure from stoichiometry is presumed to decrease with decreasing temperature down to about $1000^{\circ} \mathrm{C}$. The value of the moment at which a straight line through the points intersects the stoichiometric lattice parameter abscissa $(8.3293 \AA)$ should be the magnetic moment of stoichiometric lithium ferrite at $25^{\circ} \mathrm{C}$. This value, $4 \pi \mathrm{M}_{\mathrm{S}}=3732 \mathrm{G}$, is well within the experimental error of the values $3725 \mathrm{G}$ for the 4 hour$1000^{\circ} \mathrm{C}$ material, sharply cooled, and $3747 \mathrm{G}$ for this same material after the $900^{\circ} \mathrm{C}$ anneal, and essentially equal to the value derived below as the best-fit value for all the data: $3736 \mathrm{G}$. An independent measurement of the magnetic moment was made on a separately prepared sample by Mee, Besser, and Whitcomb (ref. 17). This sample was fired at $1000^{\circ} \mathrm{C}$ for 4 hours under 1 atmosphere oxygen, and then cooled rapidly as described above. The moment found at $25^{\circ} \mathrm{C}$ was $3720 \pm 40 \mathrm{G}$. This value is also within the experimental error of all the above values, even though the measurements were made by independent workers using a different magnetometer. This same group of workers also obtained a chemical analysis of the sample and found the ratio $\mathrm{Fe} / \mathrm{Li}=5.03$. This corresponds to a lithium deficiency of 0.6 percent; however, this is much less than the experimental analytical error for lithium and must be so regarded in this light.

\section{DISCUSSION}

The volatilization of lithium (probably as the oxide) from lithium aluminum oxide has been studied by Hummel, Sastry and Watring (ref. 18), from lithium nickel oxides by Iida (ref. 19), and a lithium nickel ferrite by Salmon and Marcus (ref. 20). It is generally accepted that spinel lithium ferrite shows a similar tendency to lose lithium.

The precipitation of $\alpha-\mathrm{Fe}_{2} \mathrm{O}_{3}$ during the $900^{\circ} \mathrm{C}$ annealing treatment is convincing evidence that lithium has been lost from NASA-ERC materials, and the increasing amount of $\alpha-\mathrm{Fe}_{2} \mathrm{O}_{3}$ with increased sintering temperature suggests that the lithium loss and the increases in magnetic moment and lattice parameter are interrelated. It is clear that stoichiometric lithium ferrite can exist in only those samples which yielded no $\alpha-\mathrm{Fe}_{2} \mathrm{O}_{3}$ precipitate and also showed no change in moment or lattice parameter, within experimental error, before and after the annealing and slow cooling treatment. Further, it is unlikely that an excess of $\mathrm{Li}_{2} \mathrm{O}$ in the structure, if this can occur, would result in a decrease in lattice parameter. Strickler and Roy (ref. 10) found 




Figure 4.- Magnetic moment versus lattice parameter for all single-phase materials regardless of sintering times or cooling rates; the $8.3293 \AA$ lattice parameter represents the value derived as the lattice parameter for stoichiometric $\mathrm{Li}_{0.5} \mathrm{Fe}_{2.5} \mathrm{O}_{4}$, and the intersection of the curve with this abscissa yields the corresponding magnetic moment: $3732 \mathrm{G}$. 
no evidence that $\mathrm{Li}_{0.5} \mathrm{Fe}_{2.5} \mathrm{O}_{4}$ does dissolve $\mathrm{LiFeO}_{2}$; this would be equivalent to excess lithium in the structure. Thus, the material yielding the minimum lattice parameter should be the one most closely approaching stoichiometric lithium ferrite. Above this temperature, lithium-deficient materials will result which will give magnetic moments which are either too high or too low depending upon the cooling rate, as shown in Figure 1 . That magnetic moment and lattice parameter values very near the stochiometric values have been obtained is no guarantee that the material is stoichiometric, since any intermediate value of the moment can be obtained by a proper choice of cooling rate. The lattice parameter would not necessarily differ greatly from the stoichiometric value in this case.

All materials fired at $900^{\circ} \mathrm{C}$ and no-higher and the materials fired only 4 hours at $1000^{\circ} \mathrm{C}$, whether rapidly cooled, slowly cooled, or annealed and very slowly cooled, showed lattice parameters within the estimated experimental error of the average value, 8.3296 $\AA$. This can be assumed to approach closely the lattice parameter of stoichiometric lithium ferrite, $\mathrm{Li}_{0.5} \mathrm{Fe}_{2 .} \mathrm{O}_{4}$, subject only to the condition that lithium ferrite will accept the full quota of lithium. There is no reason for believing that it will not. The true magnetic moment of stoichiometric lithium ferrite cannot be so directly and reliably derived. A nonferromagnetic material, when present as a second phase or impurity, such as $\alpha-\mathrm{Fe}_{2} \mathrm{O}_{3}, \mathrm{Li}_{2} \mathrm{O}$ or $\mathrm{Li}_{2} \mathrm{CO}_{3}$, will reduce the measured moment and prevent a direct measurement of the true moment. Because of the significant magnitude of the detectability limit of the NASA-ERC x-ray diffraction methods, there is no guarantee of the complete absence of these contaminants and, therefore, no assurance that the value obtained from an individual moment measurement is the true moment. The magnetic moments obtained for the various 4 -hour $-1000^{\circ} \mathrm{C}$ firings indicate the stoichiometric moment to be near $3735 \mathrm{G}$. The six curves of Figure I show a minimum divergence at about $900^{\circ} \mathrm{C}$. The average of the moments along this ordinate is only slightly smaller than this value; however, this value is not highly reliable.

If all moments are plotted versus the corresponding lattice parameters (Figure 4), a curve of much greater point density is obtained. The best-fit or least-squares line through the collection of points should pass through the intersection of the stoichiometric moment ordinate and the stoichiometric lattice parameter abscissa, 8.3293 $\AA$, the value found to be the probable lattice parameter of stoichiometric lithium ferrite (see below). The magnetic moment thus derived is found to be $3732 \mathrm{G}$, which is very close to the average of the individual measurements for the 4-hour-1000 $\mathrm{C}$ firings.

Strickler and Roy (ref. 10) state that the equilibrium oxygen pressure over lithium ferrite reaches 1 atmosphere below 
$1000^{\circ} \mathrm{C}$. The oxygen loss associated with this process and with the $\mathrm{Li}_{2} \mathrm{O}$ volatilization is not expected to generate any appreciable number of oxygen vacancies in the lattice since the binary oxides of iron show no such tendency. All such binary oxides of iron have close-packed oxygen sublattices, the variations in composition being achieved by changes in the valence state and packing density of iron. To understand the temperature-induced variations in the properties of lithium ferrite, cognizance must be taken of this fact and of the loss of lithium.

From the above, two limiting cases can now be derived: (1) those materials which are rapidly cooled under lower oxygen pressures, and (2) those materials which are slowly cooled under higher oxygen pressures. In both cases, when lithium is removed from a region of the crystal, from a selected unit cell, for example, and if that unit cell retains its full complement of 32 oxygens, the positive charge of the departed lithium must be made up in some manner. This is accomplished by the diffusion of iron into the crystal from the surface as the oxygen on the surface is removed. In the first case, applicable to rapidly cooled materials and low oxygen pressures, each vacated lithium site is reoccupied, in effect, by an $\mathrm{Fe}^{+2}$ ion diffusing in from the crystal surface. Charge neutrality is maintained by the concurrent reduction of another $\mathrm{Fe}^{+3}$ to $\mathrm{Fe}^{+2}$. The phase composition can now be represented:

$$
\mathrm{Li}_{0.5-\mathrm{x}} \mathrm{Fe}_{2-\mathrm{x}}^{+2} \mathrm{Fe}_{2.5-\mathrm{x}}^{+3} \mathrm{O}_{4}
$$

This formulation can be viewed as representing a solid solution between spinel lithium ferrite and $\mathrm{Fe}_{3} \mathrm{O}_{4}$. With few exceptions, the $\mathrm{Fe}^{+2}$ ions should be found on octahedral sites, as in the case of $\mathrm{Fe}_{3} \mathrm{O}_{4}$.

The second limiting case is applicable to lithium loss not correlated with an oxygen evolution and reduction of $\mathrm{Fe}^{+3}$ to $\mathrm{Fe}^{+2}$. In the limit the additional ions diffusing in will be $\mathrm{Fe}^{+3}$ with only one-third the vacated lithium sites so occupied. The composition of the phase can be formulated:

$$
\mathrm{Li}_{0.5-\mathrm{y}} \mathrm{Fe}_{2.5+\mathrm{y} / 3}^{+3} \mathrm{O}_{4}
$$

This picture can also be yiewed as a solid solution between spinel lithium ferrite and $\gamma-\mathrm{Fe}_{2} \mathrm{O}_{3}$, but, since $\gamma-\mathrm{Fe}_{2} \mathrm{O}_{3}$ is unstable with respect to the alpha form at these temperatures, materials deficient in lithium might be expected to show this instability to some degree under strong oxidizing conditions and dissociate into a higher lithium-content phase (spinel) and $\alpha-\mathrm{Fe}_{2} \mathrm{O}_{3}$. 
According to the above pictures, the population of the octahedral sites by magnetic cations has been increased and an increase in the measured magnetic moment should be found. It is assumed to be true that the tetrahedral site cations and the octahedral site cations generate separate magnetic sublattices which are opposed in a Neel-type configuration.

Following the above descriptions, one can calculate the lithium loss from the magnetic moment and lattice parameter increases. One method would be to consider the individual samples to be solid solutions of the end members of the series, lithium ferrite and $\mathrm{Fe}_{3} \mathrm{O}_{4}$ in the first limiting case and lithium ferrite and $\gamma-\mathrm{Fe}_{2} \mathrm{O}_{3}$ in the second. An interpolation technique (Vegard's law) would be used with the lattice parameters. These require that dependable values be available for the magnetic moments and lattice parameters of the end members. Such values were not found after limited effort, except for the lattice parameters of $\mathrm{Fe}_{3} \mathrm{O}_{4}$ and lithium ferrite and the magnetic moment of lithium ferrite (the latter two from this study, which we assume to be good values). Abrahams and Calhoun (ref. 2l) and Tombs and Rooksby (ref. 22) report the same value of 8.3940 $\pm 0.0005 \AA$ for the lattice parameter of $\mathrm{Fe}_{3} \mathrm{O}_{4}$ at $22^{\circ} \mathrm{C}$. By use of a thermal expansion coefficient provided by the former authors, a value of $8.3944 \AA$ is obtained at $28^{\circ} \mathrm{C}$, the temperature of the NASA-ERC measurements.

Another method is available for the calculation of lithium losses and was preferred to the procedure above. This method involves relating the measured magnetic moment of a particular lithium oxide deficient sample, either with or without separate oxygen loss, to these deficiencies through the proportionate change in the theoretical number of Bohr magnetons per unit weight or per unit volume. To obtain values on a volume basis, it is necessary to include a density correction which is expressed in terms of the deficiencies and the measured lattice parameters. These values, however, will not be completely independent of those derived by the Vegard's law approach. Thus, the emphasis was placed on calculation from the proportionate change in the number of Bohr magnetons per unit weight. Separate values of lithium loss were calculated by this method and by the Vegard's law method for the limiting case of the rapidly cooled samples. The results are tabulated in Table II. The details of the calculation procedure are given in Appendix A.

It should be pointed out here that two different values can be derived to express the degree of lithium volatilization: (1) a lithium loss value, and (2) a lithium deficiency value. The former represents the percentage of the original quantity of lithium volatilized; this is not equal to the lithium deficiency of the final product. The lithium deficiency represents the 
DATA CORRESPONDENCE IN FIRST LIMITING CASE FOR SHARPLY COOLED MATERIALS

\begin{tabular}{|c|c|c|c|c|c|c|c|c|c|}
\hline \multirow{2}{*}{$\begin{array}{l}\text { Sintering } \\
\text { Conditions }\end{array}$} & \multicolumn{3}{|c|}{ Calcd. $\underset{(\%)}{\text { Li Loss }}$} & \multirow{2}{*}{$\begin{array}{c}\text { Calcd. } \\
\text { Li Def. } \\
(\%)\end{array}$} & \multicolumn{2}{|c|}{$\begin{array}{l}\text { Magnetic Moments } \\
{\left[4 \pi M_{S}\right.} \\
\end{array}$} & \multicolumn{2}{|c|}{$\begin{array}{c}\text { Lattice Parameters } \\
(\AA)\end{array}$} & \multirow{2}{*}{$\begin{array}{r}\text { Density } \\
\text { Calcd. } \\
\left(\mathrm{g} / \mathrm{cm}^{3}\right.\end{array}$} \\
\hline & $\begin{array}{l}\text { From } \\
\text { Moment }\end{array}$ & $\begin{array}{l}\text { From } \\
\text { Lat. Par. }\end{array}$ & Ave. & & Measd. & $\begin{array}{l}\text { Calcd. } \\
\text { From Ave. }\end{array}$ & Measd. & $\begin{array}{l}\text { Calcd. } \\
\text { From Ave. }\end{array}$ & \\
\hline $\begin{array}{r}4 \text { hrs. }, 1000^{\circ} \mathrm{C} \\
24 \text { hrs. } 1000^{\circ} \mathrm{C}\end{array}$ & 2. & $\overline{2 .}$ & 2. & $\begin{array}{l}-* \\
1.9\end{array}$ & $\begin{array}{l}3725 \\
3769\end{array}$ & $\overline{-}$ & $\begin{array}{l}8.3295 \\
8.330_{5}\end{array}$ & $8 . \overline{3} 30_{5}$ & $\begin{array}{l}4.759 \\
4.767\end{array}$ \\
\hline $\begin{array}{r}4 \mathrm{hrs} ., 1100^{\circ} \mathrm{C} \\
24 \mathrm{hrs} .1100^{\circ} \mathrm{C}\end{array}$ & $\begin{array}{l}4.8 \\
8.0\end{array}$ & $\begin{array}{l}5.8 \\
8.5\end{array}$ & $\begin{array}{l}5.3 \\
8.3\end{array}$ & $\begin{array}{l}4.4 \\
7.0\end{array}$ & $\begin{array}{l}3808 \\
3857\end{array}$ & $\begin{array}{l}3816 \\
3861\end{array}$ & $\begin{array}{l}8.3325 \\
8.3340\end{array}$ & $\begin{array}{l}8.3322 \\
8.3340\end{array}$ & $\begin{array}{l}4.779 \\
4.790\end{array}$ \\
\hline $4 \mathrm{hrs} ., 1150^{\circ} \mathrm{C}$ & 8.7 & 8.4 & 8.6 & 7.2 & 3868 & 3865 & 8.3339 & 8.3340 & 4.792 \\
\hline $\begin{array}{r}4 \mathrm{hrs} ., 1200^{\circ} \mathrm{C} \\
24 \mathrm{hrs} ., 1200^{\circ} \mathrm{C}\end{array}$ & $\begin{array}{l}12.7 \\
13.5\end{array}$ & $\begin{array}{l}11.0 \\
13.7\end{array}$ & $\begin{array}{l}11.9 \\
13.6\end{array}$ & $\begin{array}{l}10.1 * * \\
11.6\end{array}$ & $\begin{array}{l}3928 \\
3941\end{array}$ & $\begin{array}{l}3915 \\
3942\end{array}$ & $\begin{array}{l}8.3354 \\
8.3369\end{array}$ & $\begin{array}{l}8.3359 \\
8.3369\end{array}$ & $\begin{array}{l}4.804 \\
4.811\end{array}$ \\
\hline $24 \mathrm{hrs} ., 1225^{\circ} \mathrm{C}$ & 15.8 & 13.3 & 14.6 & 12.4 & 3975 & 3957 & $8.336_{7}$ & $8.337_{4}$ & 4.815 \\
\hline 24 hrs., $1250^{\circ} \mathrm{C}$ & 18.4 & 19.6 & 19.0 & 16.3 & 4015 & 4025 & $8.340_{3}$ & 8.3399 & 4.832 \\
\hline
\end{tabular}

*Analyzed $0.6 \%$

**Analyzed $9.2 \%$ 
percentage of the lattice sites originally occupied by lithium but occupied in the final product by $\mathrm{Fe}^{+2}$ or $\mathrm{Fe}^{+3}$. (It cannot be stated that the Iithium site is occupied, in particular, by either valence state.) These definitions are followed throughout this report. In the rapid-cool case, the fractional lithium deficiency will be 5p/6-p, where $p$ is the fractional lithium loss (see Appendix C).

In Table II, the first column gives the temperature at which the samples were sintered and the time at temperature. The next three columns give the calculated lithium losses: column 2 lists values computed from the measured moments (column 6); column 3 lists the values computed from measured lattice parameters (column 8), assuming Vegard's law; and column 4 shows the average of the two loss values. These average lithium losses were used to calculate the magnetic moments and lattice parameters given in columns 7 and 9 and to calculate the densities of column 10 . The lithium deficiencies of column 5 were derived from the average losses as described above.

Both the calculated and measured moments of columns 6 and 7 of Table II are uncorrected for the density changes accompanying the oxygen and lithium losses and, therefore, are proportional to the magnetic moment per gram. Dividing these values by $4 \pi d$ $\left(d=4.759 \mathrm{~g} / \mathrm{cm}^{3}\right.$, the $\mathrm{x}$-ray density of stoichiometric lithium ferrite assuming the lattice parameter $a=8.3293 \AA$ ) yields the magnetic moments in emu/g. The stoichiometric material is generally the one sought and these values are those which would be obtained under the given sintering conditions if the product were assumed stoichiometric and the corresponding density applied.

The experimental data were analyzed as follows: values for the magnetic moment and lattice parameter of stoichiometric lithium ferrite and the lattice parameter of magnetite were determined (see Appendix A) in a manner consistent with a best least-squares fit to the data where the magnetic moment and lattice parameter data were weighted relative to the respective estimated errors. The resulting values are $3736 \mathrm{G}$ and $8.3293 \AA$ for the moment and lattice parameter of lithium ferrite and $8.3943 \AA$ for the lattice parameter of magnetite. It should be noted that a change of one unit in the least significant figure of either or both lithium ferrite values produces a change of one or more units in the next-to-least significant figure of the bestfit magnetite lattice parameter value. The lattice parameter of lithium ferrite $(8.3293 \AA)$ which gives the best fit to all the data is also the value obtained from the 4 -hour- $1000^{\circ} \mathrm{C}$ sintering with the silicon internal standard technique. The best-fit magnetic moment value differs much less than the experimental error from the values derived graphically above and from the average of the values obtained by direct measurement of the 4-hour-1000 $\mathrm{C}$ samples. 
The lithium loss as a function of the sintering temperature for sintering times of 4 and 24 hours is plotted in Figure 5 . Straight lines have been drawn through the points, although there is no assurance that lithium loss need be a linear function of temperature. Indeed, with greater lithium losses and high temperatures, deviation from linear might very well be expected. These curves indicate that the lithium loss at any selected temperature and the temperature at which lithium loss begins is a function of sintering time. Since the approach of the curves to the axis is very likely non-linear, the temperature at which volatilization begins need not be assumed to be time-dependent. It is more probable that these intercepts merely suggest the relative rates of loss, and signal the onset of rapid increases in the lithium volatilization rates. In general, some timedependence of lithium loss would be expected.

Samples were also fired at 1300 and $1400^{\circ} \mathrm{C}$, but no dependable calculations of lithium loss could be made. The peaks of the $x$-ray diffraction patterns were considerably smaller and broader and did not permit the determination of accurate lattice parameters. The peaks of $\alpha-\mathrm{Fe}_{2} \mathrm{O}_{3}$ were pronounced in both cases, indicating a two-phase material, which rendered the magnetic moment data unusable. The measured moments were considerably lower than the stoichiometric value, as would be expected.

Calculations of lithium deficiencies on the basis of the change in the number of Bohr magnetons per unit volume, using densities expressed in terms of the deficiencies and the measured lattice parameters, yielded values differing by only a few hundredths in percentage from the lithium deficiencies derived from the loss values calculated on the basis of the change in Bohr magnetons per unit weight.

Mee, Besser, and Whitcomb (ref. 17) also analyzed one lithiumdeficient material ( 4 hours, $1200^{\circ} \mathrm{C}+900^{\circ} \mathrm{C}$ anneal). The analysis showed $9.2 \pm 2.7$ percent lithium deficiency; the NASA-ERC calculated value is 10.1 percent (11.86 percent lithium loss). The difference between the analyzed and calculated values is equivalent to an analysis error of only about 1 percent. The apparently large error quoted for the analysis value represents an analysis error of only 3 percent. The agreement between these two values is surprisingly good and, when considered in conjunction with the analysis results quoted above for a stoichiometric material, suggest that the analysis may be more accurate than quoted.

A similar series of calculations for the materials cooled at moderately slow rates require modification. The $900^{\circ} \mathrm{C}$ anneal results suggest that precipitation of $\alpha-\mathrm{Fe}_{2} \mathrm{O}_{3}$ probably has started, but has not proceeded to a point that $\alpha-\mathrm{Fe}_{2} \mathrm{O}_{3}$ peaks appear in the $\mathrm{x}$-ray diffraction patterns. The view here is that the products 


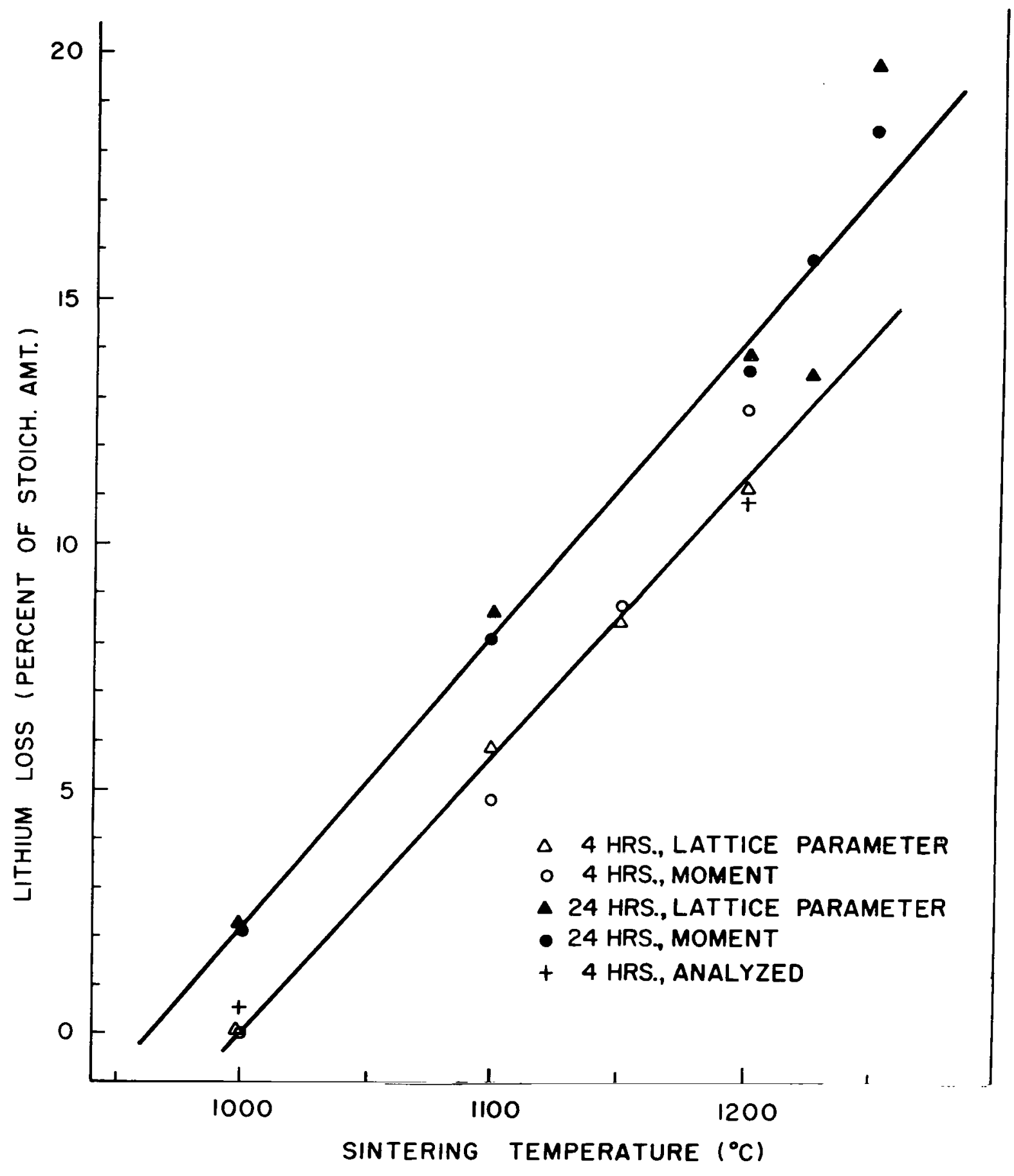

Figure 5.- Calculated lithium loss as a function of sintering temperature; values of lithium are differentiated according to time at temperature and basis for calculation. 
can be described as a mixture of a lithium ferrite phase with dissolved $\gamma-\mathrm{Fe}_{2} \mathrm{O}_{3}$ and $\alpha-\mathrm{Fe}_{2} \mathrm{O}_{3}$ precipitate. This modified calculation procedure is included in Appendix $B$ and the results are presented in Table III. The lithium loss was assumed to be the average value computed for the corresponding rapidly cooled materials (column 4, Table II). As Figure 3 shows, any additional lithium loss occurring during the cooling process should be small. The results of this calculation serve to indicate that the materials probably approach the state assumed. Attempts to calculate lithium losses directly without providing for the presence of $\alpha-\mathrm{Fe}_{2} \mathrm{O}_{3}$ as a second phase yielded values completely inconsistent with the rapid-cool results.

The percentage of the slowly cooled products estimated to be $\alpha-\mathrm{Fe}_{2} \mathrm{O}_{3}$ (column 8 ) is of the order generally considered to be the lower limit of detectability of a second phase by standard x-ray diffraction techniques. The detectability of the $\alpha-\mathrm{Fe}_{2} \mathrm{O}_{3}$ is further reduced if it is present in very fine or submicroscopic particle size. The $\alpha-\mathrm{Fe}_{2} \mathrm{O}_{3}$ precipitated after the $900^{\circ} \mathrm{C}$ anneal was detected in all cases, including the 24 -hour- $1000^{\circ} \mathrm{C}$ sample, but not the 4 -hour-1000 $\mathrm{C}$ sample. The fact that such amounts of $\alpha-\mathrm{Fe}_{2} \mathrm{O}_{3}$ were detected after the anneal, but larger calculated amounts in the slow-cooled materials were not may be either a result of better coagulation of the $\alpha-\mathrm{Fe}_{2} \mathrm{O}_{3}$ or errors in the calculated values. This apparent discrepancy is not considered significant.

In columns 5 and 6 are shown the magnetic moments (without density correction) derived for the magnetic lithium ferrite phases present in the products. Column 5 shows the value obtained from the magnetic moment, applying the lithium loss values of column 4, Table II, and the fractional $\mathrm{Fe}_{2} \mathrm{O}_{3}$ precipitation value of column 7, Table III. Column 6 shows the moments derived by calculating a lithium deficiency for the lithium ferrite phase from the lattice parameters. The agreement is very satisfactory. A first-order reaction rate for the precipitation process (instantaneous rate dependent upon the concentration of excess $\mathrm{Fe}_{2} \mathrm{O}_{3}$ dissolved) would require that the fraction of $\mathrm{Fe}_{2} \mathrm{O}_{3}$ precipitated be constant if the annealing time and cooling rates were identical. The values of column 7 show reasonably good constancy in most cases and are generally satisfactory, in view of the experimental errors and the indirect manner of derivation.

The value derived for the lattice parameter of $\gamma-\mathrm{Fe}_{2} \mathrm{O}_{3}$ corresponding to the best-fit of the data was $8.357 \AA$. Haul and Schoon (ref. 23) report a lattice parameter of $8.350 \AA$ for $\gamma-\mathrm{Fe}_{2} \mathrm{O}_{3}$ prepared by an electric arc process, and a value of $8.338 \AA$ for a material prepared by oxidation of $\mathrm{Fe}_{3} \mathrm{O}_{4}$. Van Oosterhout and Rooijmans (ref. 24) and Schrader and Büttner (ref. 25) report that $\gamma-\mathrm{Fe}_{2} \mathrm{O}_{3}$ is tetragonal with the lattice parameter $\mathrm{a}=8.33 \AA$ and 
DATA CORRESPONDENCE IN SECOND LIMITING CASE FOR SLOWLY COOLED MATERIALS

\begin{tabular}{|c|c|c|c|c|c|c|c|c|}
\hline & \multirow{3}{*}{$\begin{array}{c}\text { Sintering and cooling } \\
\text { Conditions }\end{array}$} & \multirow{3}{*}{$\begin{array}{l}\text { Li Loss } \\
\% \text { Original }\end{array}$} & \multirow{3}{*}{$\begin{array}{c}\text { Lattice } \\
\text { Parameter } \\
\text { Measd. } \\
(\AA)\end{array}$} & \multicolumn{3}{|c|}{$\begin{array}{l}\text { Magnetic Moment } \\
{\left[4 \pi M_{S} \text { (G) }\right]}\end{array}$} & \multicolumn{2}{|c|}{$\mathrm{Fe}_{2} \mathrm{O}_{3}$ Precipated } \\
\hline & & & & \multirow{2}{*}{$\begin{array}{l}\text { Measd. } \\
\text { Total }\end{array}$} & \multicolumn{2}{|c|}{ Calcd. (Magn. Phase) } & \multirow{2}{*}{$\begin{array}{l}\text { Fraction } \\
\text { of Excess }\end{array}$} & \multirow{2}{*}{$\begin{array}{l}\text { Wt. } \% \text { of } \\
\text { Sample }\end{array}$} \\
\hline & & & & & From M & From $a_{0}$ & & \\
\hline 24 & hrs. $, 1000^{\circ} \mathrm{C}, 80^{\circ} \mathrm{C} / \mathrm{hr}$ & 2.2 & $8.330_{0}$ & 3702 & 3746 & 3755 & 0.57 & 1.2 \\
\hline & hrs. $, 1100^{\circ} \mathrm{C}, 110^{\circ} \mathrm{C} / \mathrm{hr}$ & 5.3 & $8.330_{I}$ & 3769 & 3787 & 3778 & 0.10 & 0.5 \\
\hline 24 & hrs. $, 1100^{\circ} \mathrm{C}, 110^{\circ} \mathrm{C} / \mathrm{hr}$ & 8.3 & $8.33 I_{1}$ & 3777 & 3815 & 3812 & 0.12 & 1.0 \\
\hline 4 & hrs., $1150^{\circ} \mathrm{C}, 220^{\circ} \mathrm{C} / \mathrm{hr}$ & 8.6 & $8.330_{7}$ & 3787 & 3819 & 3806 & 0.10 & 0.8 \\
\hline & hrs. $, 1200^{\circ} \mathrm{C}, 220^{\circ} \mathrm{C} / \mathrm{hr}$ & 11.9 & $8.33 l_{5}$ & 3747 & 3839 & 3833 & 0.21 & 2.4 \\
\hline 24 & hrs., $1200^{\circ} \mathrm{C}, 110^{\circ} \mathrm{C} / \mathrm{hr}$ & 13.6 & 8.3317 & 3769 & 3859 & 3847 & 0.18 & 2.4 \\
\hline 24 & hrs. $, 1225^{\circ} \mathrm{C}, 110^{\circ} \mathrm{C} / \mathrm{hr}$ & 14.6 & 8.3337 & 3802 & 3874 & 3895 & 0.13 & 1.8 \\
\hline 24 & $\mathrm{hrs}, 1250^{\circ} \mathrm{C}, 110^{\circ} \mathrm{C} / \mathrm{hr}$ & 19.0 & $8.334_{0}$ & 3838 & 3921 & 3924 & 0.11 & 2.0 \\
\hline $\begin{array}{r}4 \\
+8\end{array}$ & $\begin{array}{l}\text { hrs., } 1000^{\circ} \mathrm{C}, \text { Rapid Cool } \\
\text { hrs., } 900^{\circ} \mathrm{C}, 10^{\circ} \mathrm{C} / \mathrm{hr}\end{array}$ & - & 8.3297 & 3748 & - & - & - & - \\
\hline $\begin{array}{r}24 \\
+8\end{array}$ & $\begin{array}{l}\text { hrs., } 1000^{\circ} \mathrm{C}, \text { Rapid Cool } \\
\text { hrs., } 900^{\circ} \mathrm{C}, 10^{\circ} \mathrm{C} / \mathrm{hr}\end{array}$ & 2.2 & 8.3299 & 3693 & 3744 & 3752 & 0.67 & 1.4 \\
\hline $\begin{array}{r}4 \\
+8\end{array}$ & $\begin{array}{l}\text { hrs., } 1100^{\circ} \mathrm{C}, \text { Rapid Cool } \\
\text { hrs., } 900^{\circ} \mathrm{C}, 10^{\circ} \mathrm{C} / \text { hr }\end{array}$ & 5.3 & $8.330_{4}$ & 3594 & 3743 & 3762 & 0.87 & 4.5 \\
\hline $\begin{array}{l}24 \\
+8\end{array}$ & $\begin{array}{l}\text { hrs., } 1100^{\circ} \mathrm{C}, \text { Rapid Cool } \\
\text { hrs., } 900^{\circ} \mathrm{C}, 10^{\circ} \mathrm{C} / \mathrm{hr}\end{array}$ & 8.3 & 8.3300 & 3490 & 3744 & 3755 & 0.89 & 7.1 \\
\hline $\begin{array}{r}4 \\
+8\end{array}$ & $\begin{array}{l}\text { hrs., } 1150^{\circ} \mathrm{C}, \text { Rapid Cool } \\
\text { hrs., } 900^{\circ} \mathrm{C}, 10^{\circ} \mathrm{C} / \mathrm{hr}\end{array}$ & 8.6 & $8.330_{3}$ & 3631 & 3786 & 3781 & 0.49 & 4.1 \\
\hline $\begin{array}{r}4 \\
+8\end{array}$ & $\begin{array}{l}\text { hrs., } 1200^{\circ} \mathrm{C}, \text { Rapid Cool } \\
\text { hrs., } 900^{\circ} \mathrm{C}, 10^{\circ} \mathrm{C} / \mathrm{hr}\end{array}$ & 11.9 & 8.3307 & 3588 & 3811 & 3802 & 0.48 & 5.5 \\
\hline $\begin{array}{l}24 \\
+8\end{array}$ & $\begin{array}{l}\text { hrs., } 1200^{\circ} \mathrm{C}, \text { Rapid Cool } \\
\text { hrs., } 900^{\circ} \mathrm{C}, 10^{\circ} \mathrm{C} / \mathrm{hr}\end{array}$ & 13.6 & $8.330_{4}$ & 3328 & 3757 & 3769 & 0.87 & 11.5 \\
\hline
\end{tabular}


$c / a=3.000$. The latter authors find that the cation vacancies order along a screw axis parallel to the tetragonal c-axis. It is possible that the two values reported by Haul and Schoon represent different degrees of order or partial reduction. Either could occur in an electric arc. The smaller value is to be preferred as the lattice parameter of $\gamma-\mathrm{Fe}_{2} \mathrm{O}_{3}$. Any such vacancies occurring in lithium ferrite are disordered, and it is not unlikely that such materials with disordered vacancies would have a larger lattice parameter. A small increase in lattice parameter was noted on disordering of stoichiometric lithium ferrite. Here ions of comparable size are exchanging positions rather than ions with vacancies, and a somewhat greater effect might well be expected in the latter case. The NASA-ERC value of $8.357 \AA$ for the lattice parameter for $\gamma-\mathrm{Fe}_{2} \mathrm{O}_{3}$ agrees sufficiently well, in view of the manner of derivation, that measure of support is given to the NASA-ERC interpretation.

There were indications that the precipitation of $\alpha-\mathrm{Fe}_{2} \mathrm{O}_{3}$ from the lithium-deficient materials after the $900^{\circ} \mathrm{C}$ anneal was not complete in that the amount precipitated was not directly proportional to the lithium losses calculated (column 4, Table II). The relative amount of $\alpha-\mathrm{Fe}_{2} \mathrm{O}_{3}$ appearing as a second phase can be estimated experimentally from the intensity of the strongest $\alpha-\mathrm{Fe}_{2} \mathrm{O}_{3}$ peak found in the $\mathrm{x}$-ray diffraction pattern and normalizing to the intensity of the spinel 220 peak. The intensity of the spinel 220 peak is derived essentially only from the tetrahedral site ions and should not be appreciably affected by moderate amounts of lithium deficiency. Plots of the reduced intensity of the $\alpha-\mathrm{Fe}_{2} \mathrm{O}_{3}$ peak $\left(I_{\alpha} / I_{220}\right)$ versus calculated lithium losses and versus the sintering temperature were far from linear. Plots of reduced intensity versus the calculated amount of $\alpha-\mathrm{Fe}_{2} \mathrm{O}_{3}$ precipitated showed much more linear behavior (Figure 6), giving further measure of support to the NASA-ERC assumptions.

The question arises as to whether the changes in the magnetic moment and lattice parameter could be the result of exchange of sites by octahedral lithium and tetrahedral iron, either as the sole effect or in combination with a loss of lithium and oxygen and reoccupation of the lithium sites by iron. The precipitation of $\alpha-\mathrm{Fe}_{2} \mathrm{O}_{3}$ after the anneal at $900^{\circ} \mathrm{C}$ establishes that lithium oxide has been lost and places a minimum value on the extent of this loss. The amount of $\alpha-\mathrm{Fe}_{2} \mathrm{O}_{3}$ precipitated, as calculated from the moments and lattice parameters, correlated well with the lithium loss calculated in the higher lithium losses cases. The effects on the moment and lattice parameter by any site exchange by lithium must then be confined to the differences between the observed values and the values which would be derived on the basis of the amount of $\alpha-\mathrm{Fe}_{2} \mathrm{O}_{3}$ actually precipitated. The latter was not directly determined quantitatively. Chemical analysis results indicate that the differences should be small. 


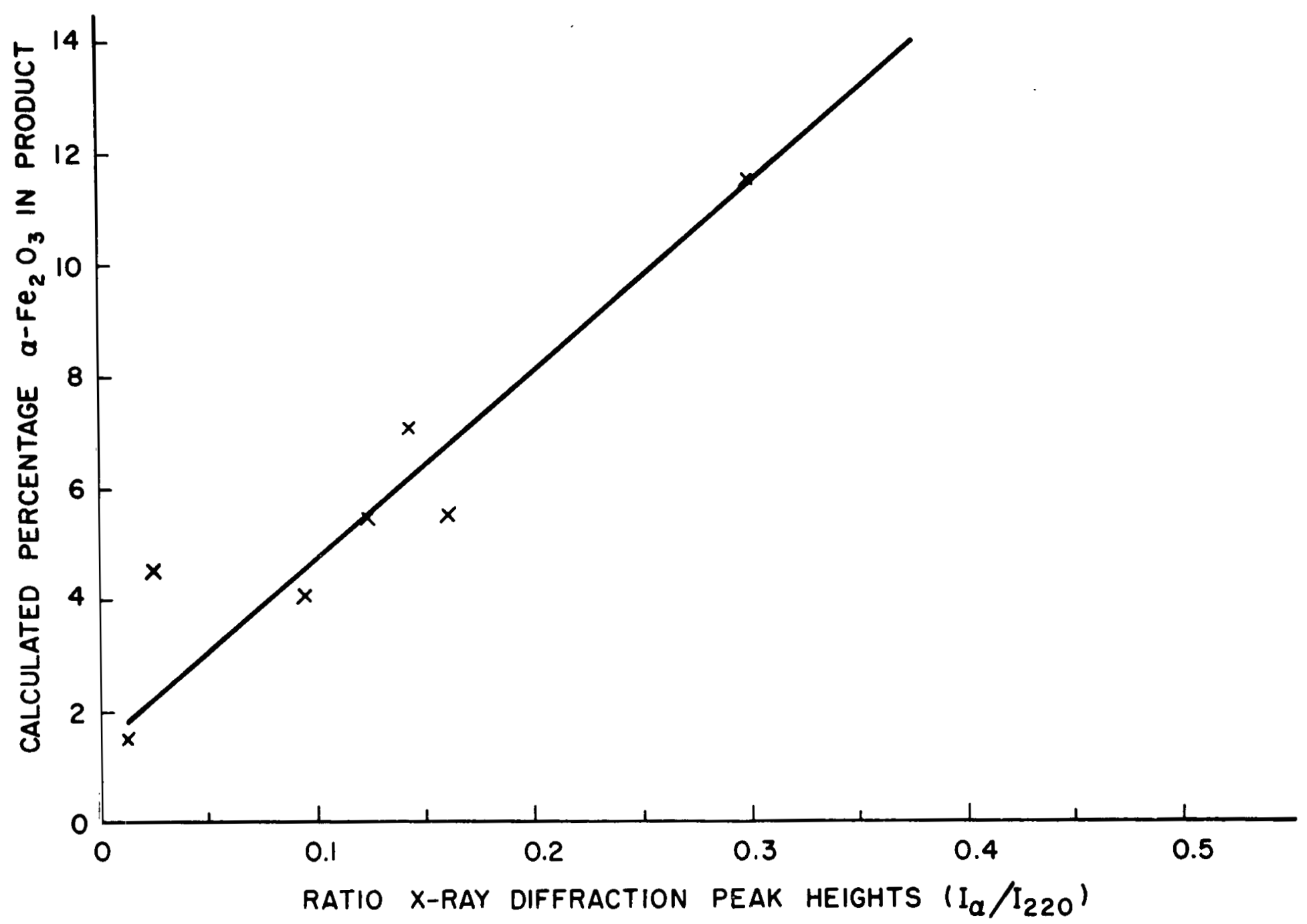

Figure 6.- Calculated percentage of $\alpha-\mathrm{Fe}_{2} \mathrm{O}_{3}$ present as a precipitate in the products after the $900^{\circ} \mathrm{C}$ anneal versus the height of the strongest $\alpha-\mathrm{Fe}_{2} \mathrm{O}_{3}$ diffraction peak normalized to the height of the 220 peak of the lithium ferrite component $\left(I_{\alpha} / I_{220}\right)$. 
The magnetic moment is very sensitive to any exchange of sites by lithium with tetrahedral iron. The lithium losses calculated above from magnetic moments and from lattice parameters agreed well within the limits of experimental error. Thus, any other mechanism proposed to account for the observed moment and lattice parameter increases, such as site exchange by octahedral lithium with tetrahedral iron, must show that some relative effect on those properties in order that a comparable degree of correlation be obtained. For the lithium loss mechanism described above, a 25 percent lithium deficiency in the final product should yield a moment increase of 15 percent and a lattice parameter increase of about $0.016 \AA ;$ a shift of the same number of lithiums to tetrahedral sites should cause a moment increase of 50 percent, which would reguire a lattice expansion of about $0.053 \AA$ to retain the same degree of correlation. A consideration of the ionic radii of $\mathrm{Li}^{+}$and $\mathrm{Fe}^{+3}$ suggests that this is reasonable. There is, therefore, no assurance that site exchanges of considerable magnitude could be established on this basis and even less in the case of small amounts, which would necessarily be the case here.

A careful study of the various structural factors which generate certain $x$-ray diffraction peaks indicates that the peaks most sensitive to site exchanges are those arising from the 111 , 210 , and 222 planes. Disorder within the octahedral sites alone would cause large changes in the intensity of the 210 peak; therefore, this peak must be eliminated from consideration. Both the 111 and 222 peaks represent cases in which the phase and scattering amplitudes of the various intensity contributions are such as to result in almost complete cancellation. A small change in any one of the contributions can thus have a relatively strong effect on resultant intensity. It has already been established that considerable lithium loss must occur. The effect on the intensity of these peaks arising from the replacement of lithium on the octahedral sites by iron without altering the tetrahedral population (lithium loss) is in the same direction as with site exchange but somewhat less in degree. One is thus restricted to differentiating between the changes in intensity resulting from the two processes, with the intensity change being smali in each case. Unfortunately the normal statistical fluctuations encountered in x-ray scanning techniques are such as to render such attempts impractical. Accurate intensities measurements might succeed in clarifying this point.

The difficulty which was experienced at NASA-ERC in attempting to achieve octahedral disorder in lithium ferrite is consistent with the observations of Kato (ref. 6), and reflects the high value of the octahedral site ordering energy calculated by de Boer, van santen and Verwey (ref. 3). The energy associated with the shift of lithium between octahedral and tetrahedral sites must certainly be greater than the energy of octahedral 
site ordering. All materials investigated which were slowlycooled or sharply cooled from temperatures of $1250^{\circ} \mathrm{C}$ and below showed well developed superlattice peaks. In view of this, there appears to be little basis for assuming any large octahedral-tetrahedral site shift by lithium. A limited amount is possible and may occur on a sharp quench of non-stoichiometric materials. The small moment increase observed in the NASA-ERC single quench into water of a stoichiometric sample is within experimental error and indicates that any shift of lithium to tetrahedral sites is very small at most.

Electronics Research Center

National Aeronautics and Space Administration

Cambridge, Massachusetts, December 1968

$129-03-15-03-25$ 


\section{REFERENCES}

1. Hoffmann, A.: Crystal Chemistry of Lithium Ferrite. Naturwissenshaften, vol. 26, p. 431, 1938 .

2. Braun, P. B.: A Superstructure in Spinels. Nature, vol. 170, p. 1123, 1952.

3. de Boer, F., van Santen, J. H., and Verwey, E. J. W.: The Electrostatic Contribution to the Lattice Energy of some Ordered Spinels. J. Chem. Phys., vol. 18, no. 8, pp. 103234,1950 .

4. Collongues, R., and Chaudron, J.: The Preparation of Lithium Ferrite. Compt. Rend., vol. 231, pp. 143-45, 1950.

5. Gorter, E. W.: Saturation Magnetization and Crystal Chemistry of Ferrimagnetic Oxides. Philips Research Report, no. 9, pp. 295-365 and 403-443, 1954 .

6. Kato, E.: Phase Transition of $\mathrm{Li}_{2} \mathrm{O}-\mathrm{Fe}_{2} \mathrm{O}_{3}$ System II--Thermal and Electric Properties of Lithium Ferrospinel LiFe, $\mathrm{O}_{8}$. Bull. Chem. Soc. Japan, vol. 31, no. 1, p. 113, 1958.

7. Schnitzler, A. D., Folen, V. J., and Rado, G. T.: Ionic Ordering Effects in the Ferromagnetic Resonance of Lithium Ferrite Monocrystals. J. Appl. Phys., vol. 31, no. 5, Suppl., p. 3485,1960 .

8. Spencer, E. G., Lepore, D. A., and Nielsen, J. W.: Measurements on Lithium Ferrite Crystals Having Near-zero Defect Concentrations. J. Appl. Phys., vol. 39, no. 2, p. 732, 1968 .

9. Remeika, J. P., and Comstock, R. L.: Properties of SingleCrystal Iithium Ferrite Grown in the ordered State. J. Appl. Phys., vol. 35, no. 1l, p. 3320, 196l.

10. Strickler, D. W., and Roy, R.: Studies in the system $\mathrm{Li}_{2} \mathrm{O}-\mathrm{Al}_{2} \mathrm{O}_{3}-\mathrm{Fe}_{2} \mathrm{O}_{3}-\mathrm{H}_{2} \mathrm{O}$. J. Am. Ceram. Soc., vol. 44, no. 5, pp. 225-30, 1961 .

11. Vassiliev, A.: Study of the Magnetic Properties of Ferrospinels Containing Lithium Ions. Ph.D. Thesis, University of Paris, 1962.

12. Baltzer, P. K.: Sintered Spinel Magnetic Cores. U. S. Patent No. 3,034,987, May 15, 1962. 
13. Nielsen, J. W., Lepore, D. A., Zneimer, J., and Townsend, G. B.: Effect of Mechanical, Thermal, and Chemical Treatment on the Ferrimagnetic Resonance Linewidth of Lithium Ferrite Crystals. J. Appl. Phys., vol. 33, no. 3, Suppl., p. 1379, 1962 .

14. Schwabe, E. A., and Campbell, D. A.: Influence of Grain Size on Square-loop Properties of Lithium Ferrites. J. Appl. Phys., vol. 34, no. 4, pt. 2, pp. 1251-53, 1963.

15. Von Aulock, W. H.: Handbook of Microwave Ferrite Materials. Academic Press, New York, p. $407 f f, 1965$.

16. Parrish, W.: X-ray Analysis Papers. Centrex Publishing Co., Eindhoven, p. 299, 1965.

17. Mee, J. E., Bener, P. J., and Whitcomb, E. C.: Monthly Reports, North American Rockwell Corp., under Contract NAS12-522, NASA-ERC, Cambridge, Mass., 1968.

18. Hummel, F. A., Sastry, B. S., and Watring, D.: Studies in Lithium Oxide Systems: II. $\mathrm{Li}_{2} \mathrm{O} \cdot \mathrm{Al}_{2} \mathrm{O}_{3}-\mathrm{Al}_{2} \mathrm{O}_{3} \cdot \mathrm{J}$. Am. Ceram. Soc., vol. 4l, no. 3, pp. 88-92, 1958.

19. Iida, Y.: Evaporation of Lithium Oxide from Solid Solution of Iithium Oxide in Nickel Oxide. J. Am. Ceram. Soc., vol. 43, no. 3, pp. 171-72, 1960.

20. Salmon, O. N., and Marcus, L.: Note on Sublimation of Lithium from Li-Ni Ferrite. J. Am. Ceram. Soc., vol. 43, no. 10, pp. 549-50, 1960 .

21. Abrahams, S. C., and Calhoun, B. A.: The Low-Temperature Transition in Magnetite. Acta Cryst., vol. 6, p. 105, 1953.

22. Tombs, N. C., and Rooksby, H. P.: Structure Transition and Antiferromagnetism in Magnetite. Acta Cryst. vol. 4, p. 474, 1951 .

23. Haul, R., and Schoon, T.: The Structure of the Ferromagnetic Iron(III) Oxide $\gamma-\mathrm{Fe}_{2} \mathrm{O}_{3}$. Z . Phys. Chem., vol. 44, series B, pp. 216-26, 1939 .

24. Van Oosterhout, G. W., and Rooijmans, C. J. M.: A New Superstructure in Gamma-Ferric Oxide. Nature, vol. 181, no. 4601, p. 44, 1958 .

25. Schrader, R., and Buttner, G.: Studies of $\gamma$-Iron(III) Oxide. Z. anorg. allegm. Chem., vol. 320, nos. 5-6, pp. 205-34, 1963. 
The fractional lithium loss, $p$, can be calculated from the measured magnetic moments (in emu/g) as follows: each gramformula ( $\mathrm{Li}_{0.5} \mathrm{Fe}_{2.5} \mathrm{O}_{4}$ ) weight of stoichiometric lithium ferrite, $A_{S}$, dissociates into a product composed, in effect, of (1-p) $A_{S}$ grams of stoichiometric lithium ferrite and (5/6) $\mathrm{pA}_{\mathrm{m}}$ grams of $\mathrm{Fe}_{3} \mathrm{O}_{4}$. The magnetic moment per gram of this product, $\sigma_{p}$, will be

$$
\sigma_{p}=\frac{(1-p) A_{s} \sigma_{s}+(5 / 6) \mathrm{pA}_{m} \sigma_{m}}{(1-p) A_{s}+(5 / 6) p A_{m}}
$$

where $\sigma_{\mathrm{s}}$ and $\sigma_{\mathrm{m}}$ are the magnetic moments in emu/g of stoichiometric lithium ferrite and $\mathrm{Fe}_{3} \mathrm{O}_{4}$, respectively. For $\sigma_{\mathrm{m}}$ a value is used derived in accordance with the scheme of the proportionate increase in the number of Bohr magnetons over that of lithium ferrite following the mechanism of the first limiting case described above:

$$
\begin{aligned}
& \sigma_{\mathrm{m}}=\left[\frac{\left(\frac{32 \mu_{\mathrm{B}} / \text { unit cell of } \mathrm{Fe}_{3} \mathrm{O}_{4}}{8 \mathrm{~A}_{\mathrm{m}} / \text { unit cell of } \mathrm{Fe}_{3} \mathrm{O}_{4}}\right)}{\left(\frac{20 \mu_{\mathrm{B}} / \text { unit cell of } \mathrm{Li}_{0.5} \mathrm{Fe}_{2.5} \mathrm{O}_{4}}{8 \mathrm{~A}_{\mathrm{s}} / \text { unit cell of } \mathrm{Li}_{0.5} \mathrm{Fe}_{2.5} \mathrm{O}_{4}}\right)}\right] \sigma_{\mathrm{s}} \\
& \sigma_{\mathrm{m}}=8 \mathrm{~A}_{\mathrm{s}} \sigma_{\mathrm{s}} / 5 \mathrm{~A}_{\mathrm{m}}
\end{aligned}
$$

Substituting in Eq. (A-1) yields:

$$
\sigma_{p}=\left[\frac{(1-p) A_{s} \sigma_{s}+(5 / 6) p A_{m}\left(8 A_{s} \sigma_{s} / 5 A_{m}\right)}{(1-p) A_{s}+(5 / 6) p A_{m}}\right]=\left[\frac{(1+p / 3) \sigma_{s}}{1-0.0683 p}\right], \quad(A-4)
$$

and rearranging gives:

$$
\mathrm{p}=\frac{\sigma_{\mathrm{p}}-\sigma_{\mathrm{s}}}{0.0683+\sigma_{\mathrm{s}} / 3}
$$




\section{APPENDIX B}

For the second limiting case, applicable to strongly oxidizing conditions, as described in the Discussion (page 13) one may assume one gram-formula weight of $\mathrm{Li}_{0} ._{5} \mathrm{O}_{4}$ to dissociate forming $(I-p) A_{S}$ grams of $\mathrm{Li}_{0 .} \mathrm{Fe}_{2} \mathrm{~F}_{5} \mathrm{O}_{4}$ and, in effect, (5/4) $\mathrm{pA}_{\mathrm{h}}$ grams of $\mathrm{Fe}_{2} \mathrm{O}_{3}$. Here $\mathrm{A}_{\mathrm{h}}$ represents the gram-formula weight of $\mathrm{Fe}_{2} \mathrm{O}_{3}$ and the other symbols have the same significance as above. It is also assumed that of the $\mathrm{Fe}_{2} \mathrm{O}_{3}$ formed during the dissociation, a fraction, $f$, remains dissolved and ( 1 - f) precipitates as $\alpha-\mathrm{Fe}_{2} \mathrm{O}_{3}$. The $\alpha-\mathrm{Fe}_{2} \mathrm{O}_{3}$ contribution to the total measured moment will be insignificant. Thus, the magnetic moment in emu/g of the mixed product, $\sigma_{p}$, will be:

$$
\begin{gathered}
\sigma_{p}=\frac{(I-p) A_{s} \sigma_{s}+(5 / 4) p f A_{h} \sigma_{g}}{(I-p) A_{s}+(5 / 4) p f A_{h}+(5 / 4) p(I-\tilde{f}) A_{h}}
\end{gathered}
$$

where $\sigma_{g}$ is the magnetic moment per gram of $\gamma-\mathrm{Fe}_{2} \mathrm{O}_{3}$. To express $\sigma_{g}$ in terms of a proportionate increase in the theoretical number of Bohr magnetons per unit weight relative to that of Iithium ferrite following the second limiting case mechanism described above, the following equation is used:

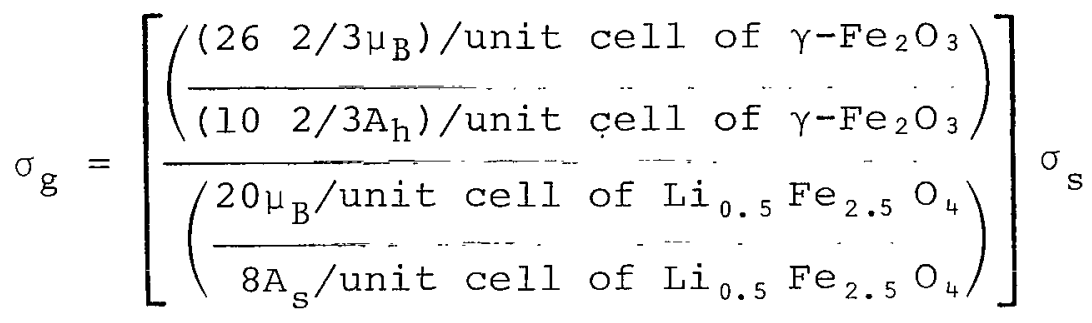

$$
\begin{aligned}
& \sigma_{g}=\left(A_{s} / A_{h}\right) \sigma_{s}
\end{aligned}
$$

Substituting in Eq. (B-I) yields:

$$
\sigma_{p}=\frac{[1-p+(5 / 4) p f] \sigma_{S}}{1-p+(5 / 4) p\left(A_{h} / A_{S}\right)}
$$

and rearranging gives:

$$
f=\frac{(1-p)\left(\sigma_{p}-\sigma_{S}\right)+(5 / 4) p\left(A_{h} / A_{S}\right) \sigma_{p}}{(5 / 4) p \sigma_{S}}
$$




\section{APPENDIX C}

The relationship between the fraction of the original Iithium lost and the fractional lithium deficiency of the final product (first limiting case) was derived as follows: C unit cells of stoichiometric $\mathrm{Li}_{0.5} \mathrm{Fe}_{2.5} \mathrm{O}_{4}$ dissociate to generate ( $1-\mathrm{p}$ ) C unit cells of lithium ferrite in which are dissolved $5 \mathrm{cp} / 6$ unit cells of $\mathrm{Fe}_{3} \mathrm{O}_{4}$, where $\mathrm{p}$ is the fractional lithium loss as calculated in appendix $A$. The total number of spinel unit cells generated are

$$
(1-p+5 p / 6) C=(1-p / 6) C .
$$

In each lithium ferrite unit cell there are four lithium sites. The total number of lithium sites in the final product becomes $4(1-p / 6) \mathrm{C}$. The total number of the original lithium sites occupied by lithium in the final product is 4 (I-p)C. The total deficiency of lithium in the product becomes

$$
4(1-p / 6) C-4(1-p) C=4(5 p / 6) C
$$

The fractional lithium deficiency is thus:

$$
\frac{4(5 / 6) p C}{4(1-p / 6) C}=\frac{5 p}{6-p}
$$




\title{
EFFECTS OF LITHIUM AND OXYGEN LOSSES \\ ON THE MAGNETIC AND CRYSTALLOGRAPHIC PROPERTIES \\ OF SPINEL LITHIUM FERRITE
}

By D. H. Ridgley, H. Lessoff, and J. D. Childress Electronics Research Center

\begin{abstract}
A study of the effects of sintering temperatures and cooling rates on the magnetic and crystallographic properties of spinel lithium ferrite shows that both the magnetic moment and lattice parameter increase with sintering temperature. Either annealing at lower temperatures or slow-cooling under oxygen causes reoxidation of the $\mathrm{Fe}^{+2}$ formed at higher temperatures with attendent decreases in moment and lattice parameter and gradual precipitation of $\alpha-\mathrm{Fe}_{2} \mathrm{O}_{3}$ as a second phase. The various products formed have been shown to be equivalent to solid solutions of spinel lithium ferrite with $\mathrm{Fe}_{3} \mathrm{O}_{4}$ on rapid cooling and to solid solution of lithium ferrite and $\gamma-\mathrm{Fe}_{2} \mathrm{O}_{3}$ with precipitation of $\alpha-\mathrm{Fe}_{2} \mathrm{O}_{3}$ on slow cooling. Lithium losses and $\alpha-\mathrm{Fe}_{2} \mathrm{O}_{3}$ precipitate amounts are calculated. The magnetic moment and lattice parameter of stoichiometric lithium ferrite have been determined: magnetic moment at $25^{\circ} \mathrm{C}: 3736 \pm 20 \mathrm{G}$; lattice parameter at $28^{\circ} \mathrm{C}: 8.3293$ $\pm 0.0005 \AA$.
\end{abstract}

STAR Categories 06 and 26 


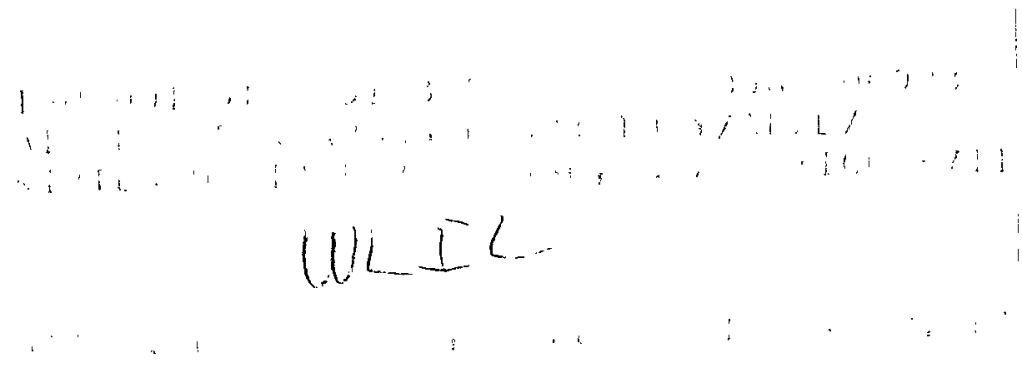

POSTMASTER: If Undeliverable (Section 158

"The aeronautical and space activities of the United States shall be conducted so as to contribute . . . to the expansion of buman knowledge of phenomena in the atmosphere and space. The Administration sball provide for the widest practicable and appropriate dissemination of information concerning its activities and the results thereof."

- National Aeronautics and Space ACt of 1958

\section{NASA SCIENTIFIC AND TECHNICAL PUBLICATIONS}

TECHNICAL REPORTS: Scientific and technical information considered important, complete, and a lasting contribution to existing knowledge.

TECHNICAL NOTES: Information less broad in scope but nevertheless of importance as a contribution to existing knowledge.

TECHNICAL MEMORANDUMS:

Information receiving limited distribution because of preliminary data, security classification, or other reasons.

CONTRACTOR REPORTS: Scientific and technical information generated under a NASA contract or grant and considered an important contribution to existing knowledge.
TECHNICAL TRANSLATIONS: Information published in a foreign language considered to merit NASA distribution in English.

SPECIAL PUBLICATIONS: Information derived from or of value to NASA activities. Publications include conference proceedings, monographs, data compilations, handbooks, sourcebooks, and special bibliographies.

\section{TECHNOLOGY UTILIZATION}

PUBLICATIONS: Information on technology used by NASA that may be of particular interest in commercial and other non-aerospace applications. Publications include Tech Briefs, Technology Utilization Reports and Notes, and Technology Surveys.

Details on the avallability of these publications may be obtained from:

SCIENTIFIC AND TECHNICAL INFORMATION DIVISION

NATIONAL AERONAUTICS AND SPACE ADMINISTRATION

Washington, D.C. 20546 